\title{
REPRESENTATIONS OF CENTRAL AND EASTERN EUROPE IN TRAVELOGUES OF ROMANIAN AND POLISH PUBLIC FIGURES
}

\author{
R A L U C A G O L E Ş T E A N U \\ Institute of History-PAN, Warsaw
}

\begin{abstract}
This article proposes a reading of Milica Bakić-Hayden's concept of "nesting orientalisms" in a wider regional context, by showing some of its first manifestations, as employed one hundred years or so ago. The debut of this phenomenon is part of the nineteenth century trend of traveling to "Eastern Europe," and of appropriating it as such, in the desire to compete with the previous century, especially with the latter's attempt of designing the map according to the dichotomy: "enlightened-ignorant peoples."

Consequently, the adoption of the concept of "Eastern Europe" by western public opinion triggered reactions from the part of the local élites expressed in the establishment of a corpus of texts, which reflect on the nearby geographical area. This effort represented in fact the third stage of the west-east dynamics that accompanied modernization in the region. The texts to be discussed in this article, apart from the century's blind faith in progress, display the obsession of being "in between," raising it to a sine qua non condition of the region; their authors often found themselves in difficulties in relation to dilemmas like professional/national identities, local/central loyalties, religious/secular views.
\end{abstract}

Keywords: Central and Eastern Europe, national identity, nesting orientalisms, east/west, geopolitics

Of course it might have been some other city, had circumstances been different and the time being different and had I been different, it might have been Paris or Chicago or even San Francisco, but because I am talking about myself, I am talking here about New York (Didion)

In her seminal essay dedicated to the mutual influences existing between us and our physical environment, Joan Didion explores our subjectivity as expressed in the tendency of imbuing with our personality the place we live in or we visit. The main idea of the work is that there can be countless places as there are countless characters, ways, and stages that we explore throughout life, nevertheless, we stick to the one that has become the extension of our 
individuality: our intellectual exploits, our preferences, our phobias, our idiosyncrasies take hold of the territory, aiming at transforming it in a tool meant to justify us as entities, from cradle to grave.

This existentialist credo finds its best expression in travel writing, a genre that is currently experiencing not only a plethora of forms (blogs, travel notes, sites dedicated to transcontinental journeys, digital cartographies of imaginary voyages to distant ages, etc.), due to technical advancement, but also a multitude of strategies employed to address newer audiences. The democratization of travel (e.g. in terms of finance and infrastructure), information, the excess of blogs led to the birth of smaller and smaller clusters of audiences who are attracted now by extra-textual features such as visuals. All these factors taken together have created the paradox according to which travel descriptions, under the pretense of "objectivity" and "first-hand information" (Bracewell 13), are forced to sell themselves in attractive packages, foregrounding the essential subjectivity that is inherent in travel writing, no matter the form it takes.

What we witness today represents the evolved stage of a process whose breakthrough was during the Enlightenment. As Wolff describes in Inventing Eastern Europe, Rousseau or Voltaire proposed new perspectives on a "world order," relevant to the emerging social classes such as the city bourgeoisie, while their writings reached more people on account of the subversiveness of their ideas in relation to the Ancien Régime (66). A century before, travel writings were usually meant to answer the interests of political leaders: a perfect example of this situation is the travelogue of the diplomat and writer Nicolae Milescu recounting his voyage to the Far East in the second half of the seventeenth century. Moreover in the sixteenth and early seventeenth centuries the travelers wrote impressions for themselves, expressing an antiquarian interest for the places they were visiting; in the next century, with the advent of the mass media, travelers expressed the views of the age, including its prejudices (Todorova 64) through ideological means.

This tendency culminated in the nineteenth century, when travelers, usually politicians or intellectuals, went abroad to get inspiration for their dreams and plans for the dominant ideologies of the century: Romanticism, positivism, or nationalism. While the texts were suffused with admiration for the unification of Italy or for the Greeks` fight for independence, the audience was presented for the first time with a clear distinction existing between two categories: aesthetics and politics. By praising the regenerative powers of nature and their superiority in relation to human things, historian Alexandru Xenopol would state the impossibility of individuals to express their feelings:

Totdeauna am căutat ca să-mi scald cugetarea şi simţirea în izvorul cel vecinic proaspăt al naturei. Ce am văzut, am spus, pe cît mi-a fost prin putinţă, ce am simţit însă a fost totdeauna deasupra puterei mele de rostire, 
căci Pentru ce-i în lume mare, graiul omului e mic/ Pentru ce-i în suflet mare, graiul său este nimic.

[I have always tried to immerse my thinking and feeling in the evergreen spring of the nature. What I saw I described to the best of my abilities, what I felt however was beyond my powers of expression, as the language of the human is tiny in comparison to the greatness of the world, and inexistent in relation to the soul] (dedication, 20, 116).

This meant that the travel writing was invested with a new dimension, as readers were invited to contemplate contemporary realities through the authors' consciousnesses. It thus came as no coincidence to find a rapid growth in what we might describe as orientalist works contrasting the east - with its numerous definitions, attributes and geographical representations - with the west that was associated with an immobile entity, eternally representing civilized public opinion. While some authors of travel notes kept amalgamating what is known today as the Middle East and even the Far East under the umbrella of the Orient/east, from the eighteenth century onwards the near East was associated almost exclusively with the area between the Baltic and the Adriatic Oceans. Larry Wolff contends in Inventing Eastern Europe that the inception of the idea of Eastern Europe as an intellectual project originated during the time of the "Enlightenment," and it was meant to emphasize the progress of the west against the "barbarianism" of the eastern lands (469). Maria Todorova and Vesna Goldsworthy elaborated on the manner in which the western fantasy worked towards categorizing unknown lands, and, ultimately, on the way the local people responded to these representations. The beauty of nature was characterized in economic terms, in other words, to make it productive, whereas the local population was reduced to insignificant proportions. When visiting the Crimea, Lady Craven imagined colonies of English families who would establish factories based on the English model and produce goods to be exported to England (Wolff 175). Yet, the very fact that the visitors could not escape their own mental maps and philosophical categories, had as a consequence the tendency to search for their own home-realities in other contexts and environments. One good example is J. P. Marat's work that under the pretext of a Polish traveler throughout western lands, issued harsh criticisms against French society, commenting that the forms of government on both sides of Europe are strikingly autocratic (Wolff 136-37). This way, Marat constructed a bridge, ascribing to Polish lands their own place on the map, even if it was a negative one.

The east offered easy possibilities of translating into simple terms the complex issues that English colonizers were facing at the time: "the uneasiness about Ireland was translated into uneasiness about Macedonia [...]; the feminist movement focused on life in the harems; the remorse about India or the Boer War was translated at the turn of the twentieth century into guilt about Turkish 
atrocities (Skopetea qtd. in Todorova 100). This transfer of ideas at a geographical distance would have significant impact on the local élites who retained the same mental pattern when visiting the west, as they issued theories of local development which combined western and eastern ideas: "If travels in Europe have provoked self-critique, they have also provided a means of selfaffirmation in comparison to Western models, using Western criteria" (Bracewell 16). It follows then that, by bringing to the east their representation of local dynamics, the western traveler served as an inspiration for the eastern traveler who happened to make it to the western lands. Starting in the last part of the seventeenth century, the eastern élite would travel to the west to complete their graduate education, to the point that this trend would become by the mideighteenth century the standard for the upper classes. The desire for emulation was accompanied by the need for representation expressed in writings and projects that would attempt to show the contribution of Eastern Europe to common European history.

The encounter with the world nearby had an ideological message from the outset, as it was foremost meant to put a distance between east and west alike. The easterner introduced new criteria of analysis, establishing differences or similarities between the various lands of Eastern Europe, and thereby distancing themselves and their countries from both the region and from what was known as Western Europe, "creating a self in opposition to an Other, however that other might be defined" (Bracewell 17). On their gradual passage to the west by coach or train, travelers had the chance to familiarize themselves with a world that was not yet the west, but significantly better than what they left home - in terms of roads or people's appearance.

In his influential work of the 1820s, Dinicu Golescu delighted the reader with the funny comment according to which he had written a detailed description of St. Stephen's Cathedral in Vienna, but, when seeing the Duomo of Milan, which was designed with additional skills and craft, he decided to remove the initial comments "in order not to write the same things twice" (36). To those who traveled further east however, as in the case of some Galician officials who visited ex-Polish lands, he areas were a proof of the superiority of Catholicism when compared to Eastern Orthodoxy, of political equilibrum instead of nihilism, of order and technological progress compared to administrative chaos (Koźmian 3, 11-12, 20). The Easterner who happened to travel further east "created a self-congratulatory image of the East-European self as uncontestably European in contrast to the Orient," "serving in fact domestic political agendas" (Bracewell, 17, 15).

This overall attitude can be best understood if interpreted from the perspective of nesting orientalisms that deals with the way in which peripheral countries conceive themselves in competition with each other (Bakić-Hayden 930). The concept raises awareness on how the countries of Eastern Europe may 
operate an imaginary "scale of Western hegemony" on which to position themselves (Bakić-Hayden 924). This can be visually represented by a conglomerate of circles that runs from the biggest to the smallest, where the biggest is defined by its proximity to the West. The framework of nesting orientalisms is, obviously, provided by Edward Said`s Orientalism, but given a localized re-interpretation. Bakić-Hayden's theories are more contextual, circumstantial, and targeted at specific issues like the Habsburg legacy, thereby representing a suitable approach to the essentially ambiguous nature and definition of concepts such as west, east, and "Eastern Europe," all of which involve questions of power dating from the Enlightenment (Wolff 132, 135).

One basic concept of this article is "Central Europe," including its theoretical and ideological extensions "East-Central Europe" (Oskar Halecki), and "Central-Eastern Europe" (Jenö Szücs, CzesławMiłosz). Such constructions were part of a long-standing European tradition that evolved around two axes: one of defining European heritage via opposition to the Muslim world; the other, of conceiving Europe as being rooted in the heritage of Roman Empire, and defined by restricted features such as Roman-Catholicism and the Latin alphabet. Among the contributors to the concept of Central Europe, Polish historian O. Halecki held the most integrative view as he did not differentiate between the inheritors of Latin and Greek political and cultural entities. To him, Europe was constantly menaced by Asia, as the latter, via the Ottoman Empire's conquest of Constantinople, had disrupted the former`s progress (Todorova 151). The Hungarian historian J. Szücs and the Polish writer C. Miłosz were concerned to create more clearly defined areas in tems of Habsburg legacy, constitutional traditions and continuity; to them, we should add the Czech writer Milan Kundera, whose concept of Central Europe is defined almost exclusively by opposition to Russia, seen as the epitome of conquest and barbarity. Obviously, the differences recorded between Halecki, on the one hand, and the three mentioned intellectuals on the other are connected to the periods in which their pieces were written. Halecki envisaged his idea of Europe in the 1950s when the model of a united Europe was gaining popularity, whereas Szücs, Miłosz, and Kundera defined their topics in the 1980s, at a time when the political model of Communism was a blatant failure. The story of the notion of Central Europe is a long and complex one, frequently associated with the notion of "Mitteleuropa," a controversial construction having at the center the unification of lands associated with German nationalism (Ungureanu 14-15). It passed through nostalgic-literary stages, to end up, after the fall of the Iron Curtain, in strategical-political attempts to secure a new position in the European order. Central Europe has also been the initiator of a heated debate concerning the degrees of westernness of the countries of that region. This effort was usually aimed at setting the borders between the more advanced countries of the area and the less "enlightened" ones. This discourse shows a particular tendency 
not so much for stressing the resemblance to the western world, but rather for distancing Central Europe from the world that is located more to the east.

Such an intellectual intricacy leads to the logical assumption that the concept was unconsciously referred to long before the official adoption of its current name. "Central Europe" will experience further representations in the future, although it is still a conundrum as to whether it will become an autonomous theoretical unit able to borrow tools of analysis from other related domains. It is worth examining this concept in detail, underlying its earlier manifestations and showing the transfer existing between the countries of the region at the level of public image; the unfolded story will be the one of a mirror that reflects back the same image but in truncated shapes, where the mirror is the concept of the west and the refracted images are the shades on the west-east scale of civilization.

\section{Being a Phanariot in Vienna and a Diplomat in Sofia}

This article deals with instances of the east as described, developed or explored in the travel writings of Romanian and Polish intellectuals and politicians active in the nineteenth century who talked about Central Europe either by direct reference or by comparing it to Eastern Europe's less advanced territories, and thereby re-examined such familiar binaries such as "we/they", and "center/periphery."

The geopolitical positions of specific countries were continually subject to debate: for example, the Poles of Galicia who, due to not enjoying significant political autonomy before the reformation of the Monarchy in 1867, came to possess an ambivalent feeling towards Vienna - the headquarters of the Austrian political establishment. The Romanians of Transylvania enjoyed significantly less political rights, but they sought to compensate for this situation by adopting a nationalist perspective. Their attitude towards Vienna was influenced by the establishment of the modern Romanian state, whose political élite based in Bucharest inspired political movements and actions of an irredentist nature. Both the Romanians and the Poles were concerned to establish their state framework as well as being involved in identity politics: Polish lands were more central or western than Transylvania, which in turn was more central or western than Bucharest, which in turn was more central or western than Sofia or Belgrade.

Finally, the choice of Romanians and Poles to be compared in the given century is rooted in the fact that the writers' real metropolis did not coincide with their ideal one. It is no wonder therefore that they would try to come to terms with this, exaggerating some traits of Vienna and being too understanding towards negative features of Cluj, Bucharest or Paris (for many intellectuals of the century, Paris was the capital of the world on the west-east axis). The case of the Galician Polish politicians is rewarding since it is usually associated with the following dilemma: traveling to Vienna was traveling west; if compared to 
traveling to Warsaw that meant traveling north (in geographical terms), but traveling east (in political terms since Warsaw was under Russian administration, which was also an enemy of the Austrian Monarchy in foreign policy matters). Yet, Warsaw was the capital of the old Polish state, and the Galician politicians would bring their important input in restoring it.

The multitude of existing sources allows their separation into various criteria mostly depending on the profession, official status, education, sensitivity of the author and their geographicals imagination (what Central or Eastern Europe primarily meant to them). Hence there is a blatant ambiguity related to the way each of the authors employs notions like west or east, and this is, as stated before, in the spirit of the concept of nesting orientalisms, since it hints at who they were, to what they preferred, and what local dynamics they reflected.

The title of this section, "Being a Phanariot in Vienna and a Diplomat in Sofia" refers to the travel writings of the boyar Dinicu Golescu from the preRomantic age; and those of the Galician Conservative politician and aristocrat Stanisław Koźmian. One telling story arose when Golescu was prevented from entering a mental hospital in Vienna on the account of his strange outfit (48), which was the clothing bearing Ottoman influences that the high ranking officials in Romanian Principalities wore at the time; the event occasioned a bitter-sad reflection from the part of the traveler on the perceived cultural gap existing between his country and the rest of Europe; he needed to adjust his ways to match the environment. In fact, his discourse could be placed in the context of a country in search for political recognition, and on account of this, he tries to make itself accepted in the circle of those which could award this recognition, their power being seen as a natural attribute of their economic and cultural advancement. Koźmian, on the other hand wrote about personalities, who, at times, seemed more important than the countries he was visiting; as a diplomat and representative of an important power at the time, he believed that the fate of small countries, or of those not independent, lay in the hands of the political élite.

It follows that not only Golescu and Koźmian's points of interest and angles but also their convictions on the righteousness of their observations were different. Golescu was putting the things in the context of a small community, being convinced that the current stage of the country was a transitory one; Koźmian expressed himself in the name of a culture that considered itself on the same pair with the western realm, hence his comments had a huamnist stance. Golescu wrote at a time when mass printing was in its infancy, and his language was a transition from old Slavonic to modern Romanian, whereas Koźmian wrote at a time when the press brought important changes to people's life. Golescu and Koźmian represent two borders, chronological as well as cultural, the first of the "easterner" overwhelmed by "civilization," the second a "westerner," and by extension a representative of a superior culture. 
Golescu (1777-1830), politician and intellectual of humanist leanings, establisher of schools and founder of academy of letters, made several trips to Western Europe reaching as far as Switzerland in the years 1824-1826 (Introduction vii). His journey to Vienna presents the reader with three areas of interest: the mental framework of the inhabitants, the nature of the institutions providing welfare for the citizens, and the relationship between technical advancement and human nature. All these topics were constantly commented with reference to the situation of the Principalities at the time, in such a way that the journey transforms itself in a pedagogical lesson. While crossing Transylvania, in the lands inhabited by the Saxons, he noticed the orderly appearance of the area, especially the laws that encouraged the sense of thrift and accumulation among the population (10), but he compared these with the lack of social justice as encountered on the lands around Cluj, where he understood the gap between the poverty of the peasants and the richness of the magnates (18). The qualities mentioned when describing the Saxons were reiterated with reference to the "Austrians" or Viennese; apart from their sense of purpose in their work (77), he additionally praised their moderation in their everyday habits. Yet he bitterly reflected on the effects that the excessive enjoyment of luxury had on the life of Romanian "bourgeoisie," and hinted at the corruption that this produced (50). As a solution, his measures were to copy the "Austrian" model, namely the reformation of schooling accompanied by a greater involvement of the priests in the life of the community (51-54). While in Vienna, Golescu enumerated all the features that made life in the city easier and happier. He did not fail to describe the range of human rights and associations implemented by the enlightened administration of Joseph I $(27,42,44)$ : the creation of charities, the spirit of comfort introduced by the postal service, the schools for disabled children were but few of the examples he provided in order to demonstrate the connection existing between rightful laws and human happiness. Golescu was amazed by the multitude of museums, scientific institutions, monuments, and, above all, places of representation that the political power built to create harmony between economic welfare and technological progress (60). The aim of the age, expressed through Viennese architecture, was the creation of beauty, of nature by human craft (72).

Golescu adopts kind of pre-Romantic mode as he wishes his society to adopt the things he deemed as worthy, even if the adoption might prove lesser than the original. A similar bias was displayed by Nicolae Suţu (1798-1871), a politician of an earlier generation, the author of the first treaty of Economics in the Principalities. Yet, in the spirit of his attachment to the Russian Empire's type of administration, his feeling of inferiority was transformed in an advantage for the place of his origin. Consequently, he criticized Vienna's architecture on the account of its "monstrous [sic] buildings that raise up in the sky instead of offering stability on the earth" (qtd. in Popescu 91), and the aesthetic impression 
is one of stuffy and narrow streets, lacking in air, space, and sun. Equally disturbing to the observer is the square of Saint Stephen's Church, as the dimensions of the monuments and houses impose on the individual to such an extent that they erode his freedom (qtd. in Popescu 91). Still, Suţu enjoyed the clean aspect, and the variation offered by the city, from green areas to cafés and riverbanks.

Mihail Kogălniceanu (1817-1891), a politician of Liberal commitment, the founder of modern Romanian historiography, and personality connected with the reformation of society, wrote letters to his family during his student years in Western Europe; he described the things noticed on his way to the destination, and these notes on Central European lands coming from a youth of seventeen offered a very trenchant view. Reaching Galicia, he observed "the dirty small settlements inhabited by Jews [sic]," whereas L'viv seemed to him a thoroughly planned city, with beautiful statues, fountains, and imposing churches (353). He perceived the relationship existing between the advancement in civilization and the spread of the railway network throughout the entire Austrian lands (362). In a similar fashion as Golescu, he praised the charities, and, above all, the restrained manners of women's dressing, arguing that the opposing tendency as existing in the Principalities deterred the appearance of the middle-class, and led to the impoverishment of the peasantry (365-66). On the other hand he suspected an oppressive administration that treated its citizens as children, fooling them with frivolous treats such as balls and cheap beer (368). Part of this establishment was the aristocracy who were ruthless in defending their lifestyle, one of parties, champagne drinking, and womanizing (363). Kogălniceanu considered that, even more dangerous than these symptoms, there was the gap existing between the irresponsible aristocracy and the bourgeoisie who grew frustrated against the government on account that the latter did not recognize the former's share in the modernization of society (363). He perceived this phenomenon through the prism of two extreme instances: the negative example was provided by the well-off people of Romanian Principalities who, attracted by the Viennese luxury and egotistical values, wasted their unearned income (368); the positive was offered by the case of neighboring Prussia, which cultivated military discipline, at the level of society as well as within aristocratic establishment, having as a result an unprecedented development (363-64).

The view of the monarchy, one of a fatherly figure who turns to toughhanded measures when the kids are not listening to him, could be also found in the notes of Nicolae Filimon (1819-1865), a writer of novels that blend positivist and Romantic ideas in an inspired way. On his way to Southern Germany, crossing the Hungarian and Czech lands, he reflected on the national traditions and symbols of the people inhabiting Transylvania and beyond, noting in a Romantic spirit the peculiarities of Hungarian music and historical architecture. Indeed, Filimon evolves through the Romantic paradigm: while residing in 
Prague, he was disturbed by what he considered an excessive and stiff bureaucracy, to such an extent that the request of the local authorities to register during his sojourn in the city, he interpreted in the light of the 1848 events. In other words, he and thereby associated himself with one of the innocent nationalities who were persecuted by the Austrian military forces via officials who sometimes were of Czech, Hungarian, or Romanian origin (Cazimir and Diaconescu 83-84).

As the Romantic solidarity was fading away, the criticism of Kogălniceanu or Filimon targeted at the Habsburg establishment was replaced by admiration, in the fashion imposed by Golescu. Yet, this time, the descriptions did not involve a conflict between an Oriental world and European traditions, but rather the attempt to discover the source of political and administrative power exercised in Transylvania, as these travelers were coming from the region.

Gheorghe Bariţiu (1812-1893), historian and founder of Romanian printed press in Transylvania, considered Vienna as the "canon" in terms of scientific and cultural progress recorded in Europe at the time: "the things I saw in my prior journeys to Western and Southern Germany could not amaze and enchant me the way those in Vienna did; not even Paris itself can impress more the one who first encountered and then explored Vienna and its collection of treasuries and scientific monuments" (qtd. in Popescu 96). Titu Maiorescu (1840-1917), politician, diplomat, one of the founders of the school of historical criticism, elaborated on the relation existing between art of high-quality and the cheerful existence of the human: "[a] superior [sic] civilization goes hand in hand with beautiful art [sic] and artistic craft; architecture, the statues on the street [...] even the elegant appeal of a ballet show, and then, even the small conveniences of everyday life like a smoother pavement, brighter lights [...] they all allure the sensitivity of the individual" (qtd. in Popescu 97).

Golescu returned from his journey to the west bearing the impression of the latter's superiority, and, on this account, wishing his fellow-nationals to emulate it. Bariţiu and Maiorescu returned re-assured by the fact that Vienna represented a good school for those who possessed less in terms of political rights and "civilization," an argument that helped them in the national fight against Hungarian domination in Transylvania. The same argument would be employed by the Transylvanian Romanian elite after 1918 to issue a view in the spirit of the nesting orientalisms: politically and culturally, the Romanians of the western part of the country were more advanced than their counterparts of the south.

The travelers of a later generation would focus on the nationality issue, similar to those of the Romantic age, but they would do this from a new angle, that of the centralized, mono-ethnic state. The journeys of Alexandru Xenopol and N. Iorga to the lands of Central Europe are good examples of this case. In 
his travelogue, Xenopol (1847-1920), a philosopher of history and politician of moderate Conservative convictions, offered an interesting blend of national selfcriticism and superiority towards the neighboring countries. In a satirical account of a trip to the spas of the Czech lands, he reflected on the amusing confusions resulting from different perceptions on time (on the west-east axis): the rules of transportation seemed too strict for eastern travelers, and, on this account, creating expectations that would not be fulfilled in certain circumstances (e.g. trusting the "Austrian precision" led the tourists to underestimate the duration of the trip from Marienbad to Karlsbad (Xenopol 167-81). It was the same "Austrian precision" that Xenopol admired in one of the journeys he made in the last decades of the nineteenth century, when stopping off in Austria on his way to Switzerland and Northern Italy: "once you have crossed, for more than one hour, an open field, where the cities and villages go hand in hand, and where the fresh crops would suddenly give way to factories of all sorts" (64). In the trip of 1888 to Bukovina, the part of Northern Moldova that was under Habsburg administration, Xenopol reflected at length on the differences arising from the type of administration as they appeared to him on the both sides of the Romanian border. He noticed the bad state of the roads of the villages located on the border, which amazed him, "knowing the renown of Austrian administration for its good roads" (4), and the carelessness of the Romanian counterparts; after visiting several villages in the area, and becoming acquainted with the exploitation of natural resources (7), he sadly concluded on the discrepancy existing between the two sides of the border, although "there was the same nation in both parts" (5).

This overall situation was interpreted in economic terms. Alcoholism rendered the situation of Romanian peasants as hopeless, but there were other communities of poor people who did not submit to alcoholism, such as the Jews in Bukovina (33). The more prosperous classes had no need to consume alcohol. This state of affairs was the outcome of respecting the law; of the role of the Church in the life of the community; and of the role of the school in shaping proper citizens. Concerning the laws, Xenopol commented that these usually applied to the tavern owners who kept strong drink in their establishments (31, 38). In relation to Romanian villages, Xenopol considered that the laws should be far more restrictive, since the evil of alcoholism was deeply rooted (39). As for the Churches, Xenopol noticed that the priests in Bukovina had a more thorough theological education when compared to the peers in Romania, but at the same time they addressed the people in more appealing ways (35). Schools were venerated by Bukovina's families, since these did not stop the children from frequenting them, but saw them instead as places for encouraging domestic activities (37).

Nicolae Iorga (1871-1940), perhaps the most prolific Romanian historian, had a research trip to the archives of the ex-Polish-Lithuanian Commonwealth. 
Although he made this journey in 1918, when the long-divided state was reunited, Iorga's travelogue contains a permanent interplay of histories. Crossing Galicia he noticed the sense of order governing the households of the people (3), as well as the different religious art, which led to building "high but not esthetic churches [sic]" (4). In Kolomyi, Stanisławów, and L'viv, apart from the Jews with their typical outfits, and "a dirty and sad population filled with speculators of foreign descent," Iorga identifed "western influences" as cultivated by the exAustrian administration, which assured continuity with the previous centuries of Polish culture $(6,41)$. In Cracow, in the city`s center, he admired the traces of a long and prosperous city life, as well as the nobility associated with it (40). Iorga found the past connections between these lands and those under Romanian administration at the time, considering that Romanians undertook commercial and cultural activities in association with Poles and Germans, but never with the "poor Ruthenians" [sic] (56). Further, he compared the lands under the exRussian administration to those under the ex-Prussian administration. In the former he saw no architectural traces of tens of years of domination, "no library, museum, cultural foundation, as those established by the old Polish nobility" $(10-11)$. In the latter Iorga found symmetry and wealth, positive things brought by the Prussians, yet not enough for replacingthe Poles' love for national symbols (32). By referring to the higher moral standards ruling the people here, when compared to the neighboring German lands (13), he made allusions to the periods of discontinuity in Polish history when the élite was forced to emigrate, a fact that led to a lack of continuity in architecture in some parts of the country, even while the ordeal of emigration assured continuity at the level of identity.

Turning now to the case of the Polish travelers to the eastern lands, our discussion starts with the travelogue of Maurycy Mann (1814-1876), journalist and editor-in-chief of the prestigious newspaper Czas, the press organ of Conservative movement in Galicia. Although, in his impressive multi-volume travelogue he did not describe the lands of what was later called Eastern Europe, he is nonetheless a good example of someone offering a more refined view of the exotic, who set the framework for the Polish discussion on the lands located further East. Mann's view is the one of the "civilized Christian European," prepared to encounter the "alien" world of the Muslims, with a distinct view on how the world there looked like, thus, not even feeling the need to confront his preconception with reality. All in all, Mann represents the archetype of the western traveler, as described by Larry Wolff: the Orient was the place where extraordinary things could happen (146).

On 25 November 1852, Mann embarked from Trieste on a journey to Alexandria, one of the stopovers on his route to Jerusalem. The journey he saw as a pilgrimage, reflecting on "the fight that the Cross had led against the ignorance of the Crescent Moon" (2), a never-ending clash between "civilization and barbarianism, which only changed the name throughout the century, but not 
the spirit; in the nineteenth century, the battle evolving around the slogan of peace and civilization" $(22,23)$. On his way to Trieste he visited Vienna, where he took the opportunity to get his hand on the essential books for the European traveler to faraway places: the Bible, the Qu'ran, Michaud's History of the Crusades, One Thousand and One Nights, and the Gotha Almanach (9). He bought gloves, pistols, cables, hatchets, spikes, all the needed objects for building up a house; and, obviously, plates, cups, and tea pots - a mobile canteen $(15,16)$. This way, Mann was ready "to say goodbye to civilization, that is to say goodbye to Europe" (Mann, 21). Upon arrival in Trieste, "this outlet to the Orient" (10), he noticed the multiculturalism of the city, but believed that the town as a whole has been corrupted due to continuous contact with the sailors (13). Similar to Iorga's impressions on the Greek-Catholic churches in Galicia, Mann proved rather intolerant regarding the aesthetic virtues of the Byzantine style of the churches which has "a strange shape [...] with some beautiful general traits, albeit there cannot be talk of a natural design" (13). From Trieste, on 8 December, he traveled to Alexandria via Corfu. Once in Alexandria, his visual memory worked after familiar canons, finding resemblance between the minarets and Venice (35). Upon arrival, he felt that the citizens resembled pirates moving en masse from one place to another (36). He witnessed "all racial types, from European, to the blackest complexions like those of Sudanese people, all versions of outfit from the rich Oriental caftan to the simple African shirt" (36). The city "presented a maze of narrow streets, wooden houses, and, above all, a mix of color, noise, dirt, in proportions that not even the filthiest Jewish village can have" $(39,41)$. This was the Orient, a world where giving tips was the rule (39), a world of the clash between East and West, with its districts adorned with elegant European villas.

The tendency to feel superior to a less advanced society, both politically and economically, as well as the temptation to search for the familiar in other places are lavishly exposed in the travelogues of two Polish officers active in the Russian army during the Crimean War of the 1850s. The first, J. M. Giżycki, crossing Moldavia on his way to the Danube in the winter of 1853 to 1854 , wrote about "the poverty of the peasants" settlements, and the sad image instilled by the endless corn fields" (qtd. in Petrica 190). The second travelogue belongs to an officer and doctor in the Russian army, who provided an extensive account of Iaşi and Bucharest's societies in 1853 to 1854. Unfortunately, the name of this contributor is not known, as the manuscript of his memoirs was accidentally discovered by a Romanian scholar in the public library of Warsaw in the 1940s (Călători străini despre Ţările Române 193). He compared Iaşi to Warsaw; the former seemed to him a beautiful city inducing a cosmopolitan atmosphere via the presence of many nationalities on the street. Yet he considered that Moldavians did not share too many common national features because "they seemed not to have anything specific: the language was a mix of foreign 
influences such as Latin, Italian, Slavonic, Greek, or Oriental, the commodities were either Austrian, Russian, or Turkish" (194). In terms of education he noticed a similarly cosmopolitan tendency; the upper classes were frequenting foreign universities, but the quality of their knowledge seemed doubtful to the observer; there was also the sexual segregation of education where women dealt with household activities, whereas the children only received religious education and some instruction in the local languages (199). While in Bucharest, he connected the absence of interest in scientific and artistic instruction with the lack of an academy, he was surprised to discover libraries and stores of optical or even musical instruments, which showed "that there were interesting people" (198). At first impressed by Iaşi`s neighboring settlement, Podu Iloaiei, "a Jewish shtetl filled with unattractive huts" (194), when he arrived in Iaşi he commented on the architecture and the city's appearance, remarking on the strong similarity existing between the styles of the houses and streets with the Oriental world: "the dwellings of Iaşi were exhibiting fences to the street, whereas the latter were narrow with even narrower sidewalks" (194). The very same type of observation was recorded by the great Polish novelist, J. I. Kraszewski (1812-1887), who visited Cetatea Albă in 1843, and was surprised by the multiculturalism found there, and by the houses whose life evolved inside. This was similar to the decorations that could be seen only behind the gates, with the latter being the only contact of the house with the street (qtd. in Panaitescu 245-51).

In Bucharest the anonymous traveler remarked on the bad state of the pavement and the narrow roads (i.e. "when two coaches are passing in the same time, there is no safety for the person walking on the sidewalk" (195)) while his positive comments were reserved for the Viennese-like fiacres, which seemed to him elegant and comfortable. The houses looked ordered and constructed with style, displaying the right proportion, particularly the palaces and villas of the rich and the newly-erected construction of the National Theatre (195). In addition, the city benefited from a network of aqueducts and fountains that catered for the main areas. When referring to the lifestyle of Bucharest's inhabitants, the traveler wrote about the multitude of cafés organized around the Turkish ritual of drinking coffee, the cake shops and fruit stores selling incredibly cheap products (196). Life in both Principalities resembled the taste of Moldavian wine, alluring and sweet, there were many restaurants, taverns and public gardens as Wallachians and Moldavians liked to party, and particularly to show off their luxurious clothing. In the parks there were parades of people of all nationalities, smoking and chatting carelessly, with a female audience displaying "European" and Oriental dresses alike, leading to contrasting visual effects (196). By contrast the boyars kissed the hand of the ruler, a custom that the observer described when visiting Moldavia (194). 
About the discrepancy existing in Romanian society of the nineteenth century, T. T. Jeż (1824-1915), wrote in his collection of pieces concercing the situation of the Principalities. His real name was Zygmunt Miłkowski, a writer of Romantic orientation, who resided in the area on several occasions in the 1850 s and 1860 s, as a representative of a French-Greek company in charge of providing cereals and grains to the Russian army camped in the region (Petrică 192). He became an expert on Romanian realities; a brochure having the title Wspótczesna Rumunia (Contemporary Romania) was published in the 1880s in the scientific-literary magazine of Humanistic-Positivist leanings - Ateneum. When visiting Bucharest, Jeż was surprised by the contrast in the buildings as well as in the peoples' appearance. The city "had a European outlook, the hotels were modern," but underneath the surface there was a sharp gap between poor and rich; the sensation was aggravated by an egotistical upper class who preferred "only Parisian things," and who spent half of their life abroad, contributing thus to the sense of envy of those who did not have the chance to travel (qtd. in Petrică 192). A special chapter in his criticism was reserved for the manners of the army`s young officers, who led a life of debauchery; their luxurious style involving fancy clothing and accessories, fancy women, and ostentatiously equipped carriages that triggered their financial ruin, and represented a bad example for other social categories (192).

We cannot ignore the resemblance of these observations to those contributed by young Kogălniceanu when referring to the military aristocratic élite living in Vienna in the mid-nineteenth century. In fact we may suppose that Kogălniceanu`s revolt against this kind of waste was connected to a domestic reality. The supposition can be validated by the similar comments of Golescu related to the women's passion for luxury back at home, feature that he compared with the thrift and sober appearance as noticed among the Viennese ladies. Another target of Jeż 's criticism was the foreigners, whom he saw as profiteers, who pretended "to convey standards of civilization in the area, being in reality concerned in amassing fortunes" (192-93). This comment should be seen in the light of his Romantic political and moral preferences, as well as his attraction to rural rather than urban lifestyles. On this account, he admired Iaşi more than Bucharest on account of its spectacular location and rustic appearance (193).

St. Koźmian (1836-1922), one of the staunchest critics of the Polish Romantic tradition in politics, a long-term Conservative associated with the political views of the Austrian establishment as implemented in Galicia, but also in foreign politics, wrote a collection of articles describing his long time journeys. In the same vein with Mann, his opinions on the visited places, from Vienna to Istanbul, would be permanently confronted with his previous impression of these countries, acquired while visiting the Universal Exhibitions of the time. The problem was that the countries participating at the Universal Exhibitions of the nineteenth century carefully selected the things to be shown to 
European audiences. When traveling to real places, his perception was coloured by prejudice. In Sofia, he found himself embroiled in a fight for the Bulgarian state's independence following the Russo-Turkish war. The people seemed to him as if from a different planet: "priests with huge beards, women of unappealing appearance, police men looking like thieves, officers half-looking like Russian guards, half like Polish uprisers, huge peasants of unusual physical power [...] they all looked like fugitives rather than the inhabitants of a country" (Koźmian 169). The mention of the Polish insurgents in this text, characters that Koźmian strongly criticized in his major work dedicated to the Romantic Uprising against the partitioning powers, as of 1863, says much about the standards used by him in interpreting reality. An outspoken Conservative, Koźmian labeled accordingly everything that looked unfamiliar to him, and, since the symbol of unrest were the Polish insurgents, he tended to employ their name to describe a reality that seemed suspicious and subversive.

Sofia, as seen through the windows of his elegant hotel, gave the impression of a city on its way to inventing itself, similar to Bulgaria which was experiencing the process on a wider scale (175). The remnants of the Ottoman administration, the minarets, were torn down and new buildings constructed, but the pace of construction was not synchronized with the demolition rate, hence the impression was of a huge building-site (178). The city, with its empty spaces, looked like a small Galician settlement (178), which provided a sense of unreality. The same could be said about the political situation: "here, like in Constantinople, there is the feeling of a pernicious, hence artificial and unhealthy foundation; the princely ruler who has to europeanize these countries governs via 'Europe's' arrangement, but he does not enjoy the recognition from the part of the diplomatic powers, bogus situation that would not resist the test of time" (179). Koźmian`s observations could be extended to all states that were under the Ottoman administration, including the Romanian Principalities. His stance was synonymous with the official Western diplomatic view on the "Eastern issue," relating to the disintegration of the Ottoman Empire.

\section{Conclusion}

The travelogues and the memoirs described in this article show a multitude of personalities, characters, stances, suppositions that cannot be separated from their political, personal, and geographical circumstances. Among the Romanian travelers, we noticed a general complex of inferiority shaped by nostalgia or a feeling of injured pride in relation to countries perceived as more western on the scale of civilization. Among the Polish travelers, we noticed a general stance of superiority rooted in the conviction of being part of a westernstyle culture; this attitude fuelled many a time a patronizing attitude towards the observed subject, which usually was a country located more wastern on the 
mental map (geographically they might have been located more to the north, or to the south).

Nevertheless, we must be wary of making generalizations, given the fact that the sources employed in this study represent but a small part of a plethora of works treating Romanians' journeys to Central Europe, or Poles' similar endeavors in the opposite direction. In dealing with the anonymous traveler to the Romanian Principalities in the 1850s, we assumed that he would have a national Polish stance, whereas he could have been a perfectly loyal citizen to his state, and also to Russian national and political ideals. Yet, the general situation of the Polish nationals under Russian administration led us to suppose that he was no exception. Another example involves writers like J. I. Kraszewski who wrote about Romania after reading Kogălniceanu's History of the Romanians. Kraszewski compiled in Polish the first synthesis of Romanian historiography while being influenced by the historical views of Kogălniceanu, a kindred Romantic spirit. This would amount to saying that there was a set of common topics that suffered slight variations, depending on age and personal chemistry. Our texts in the paper showed similar ideas as there was the case of Kogălniceanu's observations paralleling those of Jeż's in which concerns the waste as lifestyle as promoted by a certain social class.

The nineteenth century witnessed a boom in communication and transport. Filimon understood tourism's globalization; in the same fashion, Mann referred to the comfort, efficiency, and cost-effectiveness offered by the train journey, considering that traveling was not only a matter of fashion, but also of need (24). Xenopol defined the journeys as wings attached to the imagination, whereas their aim was to offer the traveler the opportunity of escaping from the dreary tasks of everyday life by unifying oneself with nature. In the end we must agree: traveling is about meeting different cultures and learning about them, but it is equally about joy, beauty, and dolce far niente.

\section{Works Cited}

Atanasiu, Lucia. "Memoriale de călătorie în literatura română din prima jumătate a secolului al XIX-lea" ("Travel Memoirs in Romanian Literature of the first half of the Nineteenth Century"). Diss. Timişoara University, Philology Department, Chair of Comparative Romanian Literature, 1977. Print.

Bakić-Hayden, Milica. "Nesting Orientalisms: The Case of Former Yugoslavia". Slavic Review 54.4 (1995): 917-931. Jstor. Web. 14 Jun. 2015.

Bracewell, Wendy. "East Looks West: East European Travel Writing on Europe 16002000". Călători români în Occident, secolele XVII-XX (Romanian Travelers to the West, Seventeenth to Twentieth Century). Eds. Nicolae Bocşan, Ioan Bolovan. 11-23. Cluj-Napoca: Institutul Cultural Român, 2004. Print.

Cazimir, Ştefan, Viorica Diaconescu, eds. Drumuri şi zări: antologie a prozei româneşti de călătorie (Paths and Horizons: Anthology of Romanian Travel Writing). Bucureşti: Sport-Turism, 1982. Print. 
Didion, Joan. "Goodbye to All That" (1967). Wikispaces.com. Web. 7 July 2015.

Dutka, Wojciech. "Podróże kulinarne Stanisława Koźmiana (1836-1922)" (The Gastronomic Travels of Stanisław Koźmian (1836-1922). Czasopismo Naukowe „,Kultura i Historia”, UMCS, Lublin (2012). Web. 16 Dec. 2012.

Filimon, Nicolae. Escursiuni în Germania meridională. Memorii artistice, istorice şi critice (Trips to Southern Germany. Artistic, Historical and Critical Memoirs). Bucureşti: Jurnalul Naţional, 1860. Print.

Goldsworthy, Vesna. Inventing Ruritania: The Imperialism of the Imagination. New Haven: Yale UP., 1998. Print.

Golescu, Dinicu. Însemnare a călătoriii mele, Constantin Radovici din Goleşti făcută în anul 1824, 1825, 1826 (Account of My Travel by C. Radovici of Goleşti, in the Years 1824, 1825, 1826). București: Editura pentru Literatură, 1964. Print.

Iorga, Nicolae. Note polone (Polish Notes). Bucureşti: Cultura Naţională, 1924. Print.

Jeż, T. T. "Współczesna Rumunia" (“Contemporary Romania”). Ateneum 2.34.6 (1884). Print.

Kogălniceanu, Mihail. "Various Letters". Scrisori vechi de studenţi (Old Student Letters). Ed. Nicolae Iorga. 352-69. Vălenii de Munte: Datina Românească, 1934. Print.

Koźmian, Stanisław. Podróże i polityka (Travels and Politics). 4 vols. Kraków: Czas, 1905. Polona. Web. 28 Jun. 2015.

Kunisch, Richard. Bucureşti şi Stambul. Schiţe din Ungaria, România şi Turcia (Bucharest and İstanbul. Notes from Hungary, Romania and Turkey). Ed. Viorica Nişcov. Bucureşti: Humanitas, 2014. E-book.

Le Rider, Jacques. Europa Centrală sau paradoxul fragilităţii (Central Europe or the Paradox of Vulnerability). Ed. Dana Chetrinescu, Ciprian Vălcan. Iaşi: Polirom, 2001. Print.

Maiorescu, Titu. Jurnal şi epistolar (Memoirs and Letters). Ed. G. Rădulescu-Dulgheru, Domnica Filimon. 8 vols. Bucureşti: Minerva, 1978, 1989. Print.

Mann, Maurycy. Podróż na Wschód (Journey to the East). Kraków: Czas, 1854. Polona. Web. 5 Jul. 2015.

Panaitescu, P. P. Călători poloni în Ţările Române (Polish Travelers to Romanian Principalities). Bucureşti: Cultura Naţională, 1930. Print.

Petrică, Ion. Confluenţe culturale româno-polone. (A doua jumătate a secolului al XIXlea) (Romanian and Polish Cultural Encounters in the Second Half of the Nineteenth Century). 190-200. Bucureşti: Minerva, 1976. Print.

Popa, Mircea. Tectonica genurilor literare (The Tectonics of Literary Genres). 260-74. Bucureşti: Cartea Românească, 1980. Print.

Popescu, Alexandru. Viena românească. Un ghid sentimental (Romanian Vienna. A Sentimental Guide). Bucureşti: Editura Fundaţiei Culturale Române, 2000. Print.

Said, Edward. Orientalism. Rev. ed. London: Penguin, 2003. Print.

"Scenografia-Memoary, czyli Pamiętnik" ("The Scenography of the Memory or Memoirs"). Călători străini despre Ţările Române în secolul al XIX-lea (Foreign Travelers about Romanian Lands in the Nineteenth Century). Ed. Daniela Buşă. Vol. VI, new series (1852-1856). 193-9. Bucureşti: Academia Română, 2010. Print. 
Suţu, Nicolae. Memoriile Principelui Nicolae Suţu mare logofăt al Moldovei 1798-1871 (The Memoirs of Prince Nicolae Suţu, Great Chancellor of Moldavia 1798-1871). Ed. Georgeta Filitti. 75-95. Bucureşti: Humanitas, 2013. Print.

Todorova, Maria. Imagining the Balkans. Updated edition. New York: Oxford UP., 2009. Print.

Ungureanu, Cornel. Mitteleuropa periferiilor (The Mitteleuropa of the Peripheries). Iaşi: Polirom, 2002. Print.

Wolff, Larry. Inventarea Europei de Est. Harta civilizatiei în epoca luminilor (Inventing Eastern Europe: The Map of Civilization on the Mind of the Enlightenment). Trans. Bianca Rizzoli. Bucureşti: Humanitas, 2000. Print.

Xenopol, Alexandru. Amintiri de călătorie (Travel Notes). Iaşi: H. Goldner, 1901. Print. 